\title{
PERAN NOTARIS DALAM PENDIRIAN PT USAHA MIKRO DAN KECIL
}

\author{
Diyan Isnaeni \\ Fakultas Hukum Universitas Islam Malang \\ Email: diyanfhuim17@gmail.com
}

\begin{abstract}
Abstrak
Disahkannya PP Nomor 8 Tahun 2021 sebagai peraturan pelaksanaan UU Nomor 11 Tahun 2020 tentang Cipta Kerja yang melahirkan Perseroan Terbatas Usaha Mikro dan Kecil sebagai etintas baru dalam dunia usaha di Indonesia, telah menunjukkan keseriusan Pemerintah Indonesia mendukung dan memberikan peluang sebesar-besarnya kepada Usaha Mikro dan Kecil untuk mengembangkan usahanya dan memberikan perlindungan hukum kepada badan hukum perorangan. Perseroan Terbatas Usaha Mikro dan Kecil dalam proses pendiriannya dapat dilakukan tanpa melalui perjanjian dan akta notaris dan hanya membuat surat pernyataan. Pendirian Perseroan Terbatas hanya melalui surat pernyataan tidak menjamin legalitas dokumen dan identitas pendiri. Legalitas Perseroan Terbatas akan diragukan dan beresiko karena bisa melakukan perbuatan melawan hukum, dan konsekuensinya Perseroan Terbatas sebagai badan hukum maka legalitas dokumen dan identitas pendiri harus dapat dipertanggungjawabkan. Sehingga dalam menjamin kepastian hukum dan perlindungan hukum, akta pendirian Pereroan Terbatas yang dibuat oleh Notaris tetap diperlukan untuk menjamin legalitas Perseroan Terbatas, keabsahan dokumen dan identitas pendiri walaupun hanya Perseroan Terbatas untuk Usaha Mikro Kecil.
\end{abstract}

Kata Kunci: PT Perorangan, Usaha Mikro dan Kecil, Kepastian Hukum

\section{Abstract}

The passing of Government Regulation Number 8 of 2021 as the implementing regulation of Law Number 11 of 2020 concerning Job Creation which gave birth to PT Micro and Small Enterprises as a new ethic in the business world in Indonesia, has shown the seriousness of the Indonesian Government to support and provide the greatest possible opportunity for Micro and Small Enterprises to develop their business and provide legal protection to individual legal entities. In the process of establishing a Limited Liability Company, Micro and Small Enterprises can be carried out without going through a notarial agreement and deed and only making a statement letter. The establishment of a Limited Liability Company only through a statement letter does not guarantee the legality of 
the documents and the identity of the founder. The legality of a Limited Company will be doubted and at risk because it can commit acts against the law, and the consequence is that the Limited Company is a legal entity, the document legality and identity of the founder must be accounted for. So that in guaranteeing legal certainty and legal protection, a Limited Liability Company establishment deed made by a notary is still needed to guarantee the legality of the limited Company, document validity and the identity of the founder even though it is only Limited Liability Companies for Micro and Small Businesses.

Keywords: Individual Limited Companies, Micro and Small Enterprises, Legal Certainty

\section{PENDAHULUAN}

\section{A. Latar Belakang Masalah}

Indonesia adalah mewujudkan masyarakat yang sejahtera, adil, makmur, yang merata baik materiel maupun spiritual sebagaimana yang dituangkan dalam pembukaan UUD1945. Didasarkan tujuan tersebut pasal 27 ayat (2) UUD 1945 menentukan bahwa "Tiap-tiap warga negara berhak atas pekerjaan dan penghidupan yang layak bagi kemanusiaan". Pemerintah telah melakukan berbagai upaya untuk menciptakan dan memperluas lapangan kerja dalam rangka penurunan jumlah pengangguran dan menampung pekerja baru serta mendorong pengembangan Koperasi dan Usaha Mikro, Kecil, dan Menengah dengan tujuan untuk meningkatkan perekonomian nasional yang akan dapat meningkatkan kesejahteraan masyarakat

Upaya pemerintah dalam mewujudkan pasal 27 ayat 2 UUD 945 dibentuklah Undang Undang Nomor 11 Tahun 2020 tentang Cipta Kerja (UU Cipta Kerja) yang disahkan pada tanggal 2 November Tahun 2020 dan dituangkan dalam Lembaran Negara Republik Indonesia RI Tahun 2020 Nomor 245. Perhatian khusus Undang-Undang Nomor 11 Tahun 2020 dari Bab V dan Bab VI UU Cipta Kerja adalah Pasal 2 ayat 1 (d), (b), dan (c) dengan didasari pada azas kebersamaan, kepastian hukum, dan kemudahan berusaha tanpa mengabaikan asas-asas lainnya.

Tidak berlebihan kiranya untuk menyatakan bahwa semangat kemudahan berbisnis di Indonesia dan target pemerintah untuk menaikkan peringkat Ease of Doing Business (EoDB) pada tahun 2021 dari peringkat ke-73 menjadi peringkat ke-40 dunia menjadi latar belakang filosofis dan sosiologis kemudahan pendirian Perseroan Terbatas Perseorangan di dalam Pasal 190 UU Cipta Kerja yang mengubah dan menambah ketentuan- 
ketentuan di dalam UU Perseroan Terbatas Indonesia (Indonesian Company Law) tentang Usaha Mikro Kecil sebagai badan hukum PT Perseorangan ${ }^{1}$.

Salah satu tujuan UU Cipta Kerja adalah menciptakan dan meningkatkan lapangan kerja dengan memberikan kemudahan, perlindungan, dan pemberdayaan terhadap koperasi dan Usaha Mikro KecilMenengah (UMK-M) serta industri dan perdagangan nasional sebagai upaya untuk dapat menyerap tenaga kerja Indonesia yang seluas-luasnya dengan tetap memperhatikan keseimbangan dan kemajuan antar daerah dalam kesatuan ekonomi nasional di tengah persaingan yang semakin kompetitif dan tuntutan globalisasi ekonomi. UMK-M mempunyai peran yang sangat vital dalam pembangunan dan pertumbuhan ekonomi, tidak hanya di negara sedang berkembang, namun juga di negara maju. UMK-M sangat penting tidak hanya karena menyerap paling banyak tenaga kerja, namun juga karena kontribusinya terhadap pembentukan atau pertumbuhan domestik bruto paling besar dibandingkan dengan jenis usaha besar

UMK-M memiliki kontribusi sebesar 60\% dari total Produk Domestik Bruto Indone dan berdasarkan catatan Badan Pusat Statistik menyerap tenaga kerja paling banyak yaitu sebesar $97 \%$ dan $99 \%$ dari total lapangan kerja. Kenaikan jumlah UMK-M, dalam kurun waktu 2 tahun dari Tahun 2018 di atas 8 juta orang, yakni 64,2 juta UMK-M meskipun penting digarisbawahi dengan perkiraan cukup banyak rekaman data berulang atas pelaku UMK-M yang sama ${ }^{2}$

UMK-M memiliki kontribusi yang sangat besar dan krusial bagi perekonomian secara makro. Berdasarkan data yang dilaporkan oleh Kementrian Koperasi dan UKM RI, secara jumlah unit UMK-M memiliki pangsa sekitar 99,99\% (62.9 juta unit) dari total keseluruhan pelaku usaha di Indonesia (2017), sementara usaha besar hanya sebanyak 0,01\% atau sekitar 5400 unit. Terkait dengan total penyerapan tenaga kerja, UMK-M menyerap sekitar 116,63 juta (97.05\%) jiwa, sementara Usaha Besar menyerap tenaga kerja sebesar 3,58 juta (2.95\%) jiwa. Dalam hal penyerapan tenaga kerja, UMK-M memiliki peran yang sangat besar. Pada kenyataannya, walaupun UMK-M memiliki peran yang sangat besar dalam hal penyerapan tenaga kerja dan pangsa yang besar, UMK-M masih banyak yang belum berbadan hukum. Berdasarkan pencatatan yang dilakukan oleh Badan Ekonomi

\footnotetext{
${ }^{1}$ Arjana Bagaskara Solichin, PerseroanTerbatas Perseorangan Dari Kacamata Hukum Perseroan: Suatu Terobosan Baru dalam Kemudahan Berbisnis di Indonesia, https 7://www.linkedin.com/pulse/perseroan-terbatas-perseorangan-dari-kacamata-hukumarjana/?trk=public_profile_article_view diakses tgl 13 april 2021

2 (https://www.hukumonline.com/berita/baca/lt6035cf5909bc5/melihat-kembalikemudahan-berusaha-umkm-di-uu-cipta-kerja/)diakses tanggal 9 april 2021
} 
Kreatif, 96\% UMK-M belum berbadan hukum atau belum memiliki payung hukum, sedangkan yang berbentuk Perseroan Terbatas (PT) hanya 0,1\% saja $^{3}$

Sebagai peraturan pelaksanaan UU Cipta Kerja yang memberikan kemudahan, perlindungan dan mempermudah khususnya terhadap Usaha Mikro dan Kecil pemerintah sebagaimana diatur dalam pasal 153A, telah mengeluarkan Peraturan Pemerintah Nomor 8 Tahun 2021 tentang Modal Dasar Perseroan Serta Pendaftaran Pendirian Perubahan dan Pembubaran Perseroan yang Memenuhi Kriteria Untuk Usaha Mikro dan Kecil. yang ditetapkan tanggal 2 Februari Tahun 2021.

Peraturan Pemerintah Nomor 8 Tahun 2021 ini merupakan salah satu dari 49 aturan turunan UU Cipta Kerja. Dalam UU Cipta Kerja, Pemerintah mewujudkan kemudahan dalam berusaha melalui hadirnya jenis badan hukum baru, yaitu perseroan perorangan dengan tanggung jawab terbatas atau sole proprietorship with limited liability. Dengan telah disahkannya PP Nomor 8 Tahun 2021 semakin menujukkan keseriusan pemerintah untuk memberikan peluang sebesar-besarnya kepada Usaha Mikro dan Kecil untuk mengembangkan usahanya dan memberikan perlindungan hukum kepada badan hukum perorangan.

Berdasarkan ketentuan tersebut Perseroan Terbatas untuk Usaha Mikro dan Kecil bisa sebagai perusahaan berbadan hukum yang hanya didirikan oleh satu orang atau perseroan perseorangan. Perseroan perseorangan ini bersifat one-tier. Artinya, pemegang saham tunggal sekaligus merangkap sebagai direktur tanpa perlu adanya komisaris. Di samping itu proses pendiriannya tanpa memerlukan akta pendirian yang dikeluarkan oleh notaris. Pendirian dilakukannya hanya berdasarkan surat pernyataan pendirian berbahasa Indonesia yang didaftarkan secara elektronik kepada Kementrian Hukum dan Hak Asasi Manusia (Kemenkumham) yang memuat maksud dan tujuan, kegiatan usaha, modal dasar, dan keterangan lain yang berkaitan dengan pendirian Perseroan Terbatas,sehingga tidak perlu menunggu keputusan dari Menteri.

Berbeda dengan pendirian Perseroan Terbatas yang diatur dalam Undang-Undang Nomor 40 Tahun 2007 tentang Perseroan Terbatas, (selanjutnya disingkat dengan Undang-Undang PT) pasal 7 ayat

\footnotetext{
${ }^{3}$ https://grfandcolawfirm.com/omnibus-law-ruu-cipta-kerja-kini-pendirian-badanhukum-dapat-dilakukan-oleh-1-orang/ 12 april2021
} 
Perseroan didirikan oleh 2 (dua) orang atau lebih dengan akta notaris yang dibuat dalam bahasa Indonesia, kemudian ayat (4) bahwa Perseroan memperoleh status badan hukum pada tanggal diterbitkannya keputusan menteri mengenai pengesahan badan hukum Perseroan. Dari ketentuan ini status badan hukum PT baru diperoleh setelah setelah adanya keputusan dari Menteri

Sebenarnya pendirian Persoran Terbatas yang bisa dilakukan tanpa adanya akta notaris sebagaimana dalam UU Cipta Kerja maupun dalam Peraturan Pemerintah Nomor 8 Tahun 2021 menurut Aulia Taufani SH Ketua Bidang Ristek PP Ikatan Notaris Indonesia (PP INI), menegaskan bahwa hal tersebut bisa dilaksanakan sepanjang pendirian PT bersifat deklaratif dan hanya memerlukan modal kecil.

\section{B. Rumusan Masalah}

Berdasar ketentuan-ketentuan baru terkait dengan pendirian badan usaha yang berbentuk badan hukum khususnya PT Usaha Kecil Mikro tersebut yang menjadi permasalahan hukumnya adalah bagaimana peran notaris dalam pendirian Perseroan Terbatas Usaha Mikro Kecil dalam perspektif kepastian berdarkan Peraturan Pemerintah Nomor 8 Tahun 2021.

\section{METODE PENELITIAN}

Pada penelitian ini penulis menggunakan penelitian hukum normatif. Penelitian hukum normatif menurut Mukti Fajar ND dan Yulianto adalah penelitian hukum yang meletakkan hukum sebagai sistem norma. Sistem norma yang dimaksud adalah mengenai asas-asas, norma, kaidah dari peraturan perundang-undangan, putusan pengadilan, perjanjian serta doktrin (ajaran). ${ }^{4}$ Pendekatan penelitian yang digunakan adalah pendekatan perundang-undangan (statute approach) dan pendekatan konseptual (conceptual approach).Menggunakan pendekatan perundang-undangan penelitian normatif ini karena yang akan di analisa adalah aturan hukum yang menjadi fokus sekaligus tema sentral suatu Pasal 153 A dan F UU Cipta Kerja dan pasal 2 dan pasal 6 PPNomor 8 tahun 2021 dan UU No 30 Tahun 2004 tentang Jabatan Notaris Sedangkan pendekatan konseptual beranjak dari pendapat para sarjana dan doktrindoktrin yang berkembang dalam ilmu hukum. Dengan demikian akan ditemukan ide-ide yang melahirkan pengertian-pengertian hukum, konsepkonsep hukum, dan asasasas hukum yang relevan dengan isu yang dihadapi.

\footnotetext{
${ }^{4}$ Mukti Fajar ND dan Yulianto Achmad, 2010, Dualisme Penelitian Hukum Normatif dan Hukum Empiris, Yogyakarta, Pustaka Pelajar, h. 34.
} 
Sebagai Sumber bahan hukum primer dalam penelitian normatif ini mengindentifikasi regulasi yang terkait Undang -Undang nomor 40 Tahun 2007 tentang Perseroan Terbatas, Undang-Undang Nomor 30 tahun 2004 tentang Jabatan Notaris, Undang-Undang Nomor 11 Tahun 2020 tentang Cipta kerja, dan Peraturan Pemerintah Nomor 8 Tahun 2021 tentang Modal Dasar Perseroan Serta Pendaftaran Pendirian Perubahan dan Pembubaran Perseroan yang Memenuhi Kriteria Untuk Usaha Mikro dan Kecil. Bahan hukum sekunder dalam penelitian ini terdiri dari buku-buku teks, jurnaljurnal hukum, para sarjana, dan hasil penelitian hukum, yang dapat memberikan penjelasan mengenai bahan-bahan hukum primer. Sedangkan bahan hukum tersier itu sendiri merupakan bahan hukum yang memberikan petunjuk maupun penjelasan terhadap bahan hukum primer maupun bahan hukum sekunder yakni berupa kamus. Bahan ini menjadi penting karena mendukung dalam proses analisis hukumnya. Bahan hukum tersier yang digunakan juga hanya bahan hukum yang berhubungan secara langsung dengan materi penelitian ini

\section{PEMBAHASAN}

\section{Peran notaris dalam pendirian Perseroan Terbatas (PT)}

Sebagaimana diuraikan dalam penjelasan Undang-Undang PT bahwa pembangunan perekonomian nasional yang diselenggarakan berdasarkan demokrasi ekonomi dengan prinsip kebersamaan, efisiensi yang berkeadilan, berkelanjutan, berwawasan lingkungan, kemandirian, serta menjaga keseimbangan kemajuan dan kesatuan ekonomi nasional bertujuan untuk mewujudkan kesejahteraan masyarakat.

Salah satu bentuk usaha yang mempunyai peranan penting dalam perekonomian adalah Perseroan Terbatas (PT), dalam pasal 1 UU PT diterangkan yaitu badan hukum yang merupakan persekutuan modal, didirikan berdasarkan perjanjian dan melakukan kegiatan usaha dengan modal dasar seluruhnya terbagi dalam saham dan memenuhi persyaratan yang ditetapkan dalam UUPT serta peraturan pelaksanaannya. Kata "perseroan" menunjuk pada modalnya yang terdiri atas sero (saham) sedangkan kata "terbatas" menunjuk pada pertanggung jawab pemegang saham yang tidak melebihi nilai nominal saham yang diambil bagian dan yang dimilikinya. ${ }^{5}$ Jika ditinjau dari segi hukum perjanjian, pendirian Perseroan sebagai badan hukum, bersifat "kontraktual" (contractual, by contract") yakni berdirinya perseroan merupakan akibat yang lahir dari

${ }^{5}$ Gunawan Widjaja, 2008, 150 Tanya Jawab Tentang Perseroan Terbatas, Forum Sahabat, Jakarta, h. 3 
perjanjian. Selain bersifat kontraktual, juga bersifat "konsensual" berupa adanya kesepakatan untuk mengikat perjanjian mendirikan perseroan. ${ }^{6}$

Menurut Munir Fuady dapat diartikan pula bahwa Perseroan Terbatas sebagai suatu asosiasi pemegang saham yang diciptakan oleh hukum dan diberlakukan sebagai manusia semu (artificial person) oleh pengadilan, yang merupakan badan hukum karenanya sama sekali terpisah dengan orang-orang yang mendirikannya dengan mempunyai kapasitas untuk bereksistensi yang terus menerus dan sebagai suatu. badan hukum, perseroan terbatas berwenang untuk menerima, memegang dan mengalihkan harta kekayaan, menggugat atau digugat dan melaksanakan kewenangankewenangannya lainnya yang diberikan oleh hukum yang berlaku?

Dengan disahkannya UU Cipta Kerja dan PP Nomor 8Tahn 2021 difinisi PT berubah menjadi badan hukum yang merupakan persekutuan modal, didirikan berdasarkan perjanjian, melakukan kegiatan usaha dengan modal dasar yang seluruhnya terbagi dalam saham atau badan hukum perorangan yang memenuhi kriteria Usaha Mikro dan Kecil sebagaimana diatur dalam peraturan perundang-undangan mengenai Usaha Mikro dan Kecil.

Perseroan Terbatas sebagai badan hukum, perusahaan tersebut harus mengikuti tata cara pembuatan, dan pengumuman sebagaimana diatur dalam Undang-Undang Nomor 40 Tahun 2007 tentang Perseroan Terbatas, yang telah dirubah dalam 153A Undang-Undang Nomor 11 Tahun 2020 tentang Cipta Kerja dan diatur lebih lanjut dalam Peraturan Pemerintah Nomor 8 Tahun 2021. Sebelumnya dalam Pasal 7 ayat (1) Undang-undang Perseroan Terbatas ditegaskan bahwa Perseroan didirikan oleh 2 (dua) orang atau "lebih" dengan akta notaris yang dibuat dalam bahasa Indonesia. Dalam definisi atau persyaratan ini terdapat unsur-unsur pokok: "oleh dua orang orang", "akta notaris" dan "bahasa Indonesia". Dalam perjanjian pendirian Perseroan Terbatas diperlukan akta notaris karena akta yang demikian merupakan akta otentik. ${ }^{8}$

Akta Notaris berperan penting dalam menciptakan kepastian hukum karena sifat otentiknya dan dapat digunakan sebagai alat pembuktian yang kuat dan penuh bila terjadi masalah yang berhubungan dengan akta tersebut. Akta otentik dipandang sebagai suatu alat bukti yang mengikat dan

${ }^{6}$ M. Yahya harahap, 2016, Hukum Perseroan Terbatas, cet.6, Sinar Grafika, Jakarta, h. 35 .

${ }^{7}$ Munir Fuady, 2003, Perseroan Terbatas Paradigma Baru, PT. Citra Aditya Bakti Bandung, h. 2

${ }^{8}$ I.G. Rai Widjaya, 2015 Hukum Perusahaan Megapoint Divisi dari Kesaint Blanc, Bekasi Indonesia, h. 15 
sempurna, artinya bahwa apa yang ditulis perjanjian pendirian Perseroan Terbatas yang dilakukan oleh para pendiri tersebut dituangkan dalam suatu akta notaris yang disebut dengan "Akta Pendirian". Akta Pendirian ini pada dasarnya mengatur di dalam akta tersebut harus dipercaya kebenarannya dan tidak memerlukan tambahan alat bukti lain. Jika yang diajukan bukan akta notaris maka permohonan pengesahan akta pendirian Perseroan terbatas dapat ditolak oleh Menteri Kehakiman, sehingga akan berakibat Perseroan Terbatas tidak berbadan hukum. berbagai macam hak-hak dan kewajiban para pihak pendiri perseroan dalam mengelola dan menjalankan Perseroan Terbatas tersebut ${ }^{9}$.

Badan hukum merupakan suatu badan yang dapat bertindak dalam lalu lintas hukum sebagai subjek hukum dan memiliki kekayaan yang dipisahkan dari kekayaan pribadi pengurusnya. Badan hukum adalah suatu subjek yang independen atau mandiri dari pendiri, anggota atau penanam modal dan badan hukum tersebut. Badan ini, seperti halnya manusia, memiliki kewajiban-kewajiban hukum seperti membayar pajak dan mengajukan izin kegiatan bisnis atas namanya sendiri. Filosofi pendirian badan hukum adalah bahwa dengan kematian pendirinya, harta kekayaan badan hukum itu diharapkan masih mendapat manfaat bagi orang lain. Oleh karena itu, hukum menciptakan suatu kreasi "sesuatu" yang oleh hukum kemudian dianggap atau diakui sebagai subjek mandiri, seperti halnya orang (naturljk persoon). Kemudian, "sesuatu" itu oleh ilmu hukum disebut sebagai badan hukum. ${ }^{10}$

Notaris sebagai pejabat umum yang berwenang untuk membuat akta otentik dalam menjalankan tugasnya didasarkan Undang Undang Republik Indonesia Nomor 30 Tahun 2004 Tentang Jabatan Notaris (UUJN) yang telah dirubah dengan Undang-Undang Nomor 2 Tahun 2014, Berdasarkan Pasal 1 angka 1 Undang-Undang Nomor 2 Tahun 2014 Tentang Perubahan atas Undang-Undang Nomor 30 Tahun 2004 tentang Jabatan Notaris menyatakan bahwa Notaris merupakan pejabat umum yang memiliki kewenangan membuat akta-akta terkait tindakan, perjanjian dan keputusankeputusan yang oleh perundang-undangan umum diwajibkan atau para yang bersangkutan supaya dinyatakan dalam surat yang bersifat otentik, menentukan tanggalnya, menyimpan aktanya dan memberikan grosse (salinan sah), salinan dan kutipannya, dan semuanya itu selama pembuatan akta-akta itu tidak juga diwajibkan kepada pejabat atau khusus menjadi kewajibannya.

\footnotetext{
${ }^{9}$ R. Subekti, 1978, Hukum Pembuktian, Pradnya Paramita, Jakarta, h 27.

${ }^{10}$ Rudhi Prasetya, 2004, Kedudukan Mandiri Perseroan Terbatas, Citra Aditya Bakti, Bandung, h. 28.
} 
Selanjutnya Pasal 15 ayat (1) nya menyatakan bahwa Notaris berwenang membuat akta autentik, sepanjang pembuatan akta-akta tersebut tidak ditugaskan atau dikecualikan kepada pejabat atau orang lain. Dengan demikian Notaris berwenang membuat akta sepanjang dikehendaki oleh para pihak atau menurut aturan hukum wajib dibuat dalam bentuk akta autentik. Pembuatan akta tersebut harus berdasarkan aturan hukum yang berkaitan dengan prosedur pembuatan akta Notaris, sehingga Jabatan Notaris sebagai Pejabat Umum tidak perlu lagi diberi sebutan lain yang berkaitan dengan kewenangan Notaris. ${ }^{11}$

Peran Notaris terkait bantuan memberi kepastian hukumnya dan perlindungan hukumnya bagi masyarakat sangatlah penting. Peran Notaris ini lebih bersifat pencegahan atau preventif akan terjadinya masalah hukum di masa datang dengan membuat akta otentik terkait dengan status hukum, hak dan kewajiban seseorang dalam hukum, dan lain sebagainya yang berfungsi sebagai alat bukti yang paling sempurna di pengadilan yaitu dalam hal terjadi sengketa hak dan kewajibannya itu. ${ }^{12}$

Dalam pendirian Perseroan Terbatas kewenangan untuk menuangkan semua perbuatan, perjanjian dan penetapan yang dikehendaki oleh pihakpihak oleh undang-undang diberikan kepada notaris dengan tujuan mengkonstantirkannya ke dalam sebuah akta autentik sehingga akta yang dibuatnya memliki kekuatan bukti yang kuat, lengkap dan memliki keabsahan sebagai akta autentik yaitu berupa akta pendirian perseroan terbatas. Akta Notaris berperan penting dalam menciptakan kepastian hukum karena sifat otentiknya dan dapat digunakan sebagai alat pembuktian yang kuat dan penuh bila terjadi masalah yang berhubungan dengan akta tersebut.

Notaris dituntut pula memenuhi semua ketentuan-ketentuan jabatan Notaris dan peraturan-peraturan lainnya yang terkait dalam Akta Pendirian PT. Notaris dalam hal ini adalah sebagai pengkaji apakah kehendak para pihak tersebut tidak bertentangan dengan peraturan perundang-undangan yang berlaku, Notaris dalam melaksanakan jabatanya juga harus berpijak kepada UUJN. Hal tersebut dilakukan oleh Notaris sebagai bentuk kewajiban untuk menyampaikan syarat-syarat autentisitas, keabsahan dan sebab-sebab kebatalan suatu akta, juga sebagai sikap preventif adanya cacat hukum Akta Notaris yang dapat mengakibatkan hilangnya autentisitas dan

${ }^{11}$ Tan Thong Kie, 2015, Studi Notariat: Beberapa Mata Pelajaran dan Serba Serbi Praktek Notaris, Cetakan 3, Ichtiar Baru Van Hoeve, Jakarta, h 160

${ }^{12}$ Sjaifurahman \& Habi Adjie. 2011. Aspek Pertanggungjawaban Notaris dalam Pembuatan Akta.Bandung. CV. Mandar Maju. Hlm. 7-8. 
batalnya Akta Notaris, yang dapat menimbulkan kerugian kepada masyarakat, terutama pihak-pihak yang berkepentingan. ${ }^{13}$

\section{Peran notaris dalam pendirian PT Usaha Mikro Kecil dalam perspektif kepastian hukum berdasarkan PP NOMOR 8 TAHUN 2021}

Disahkannya UU Nomor 11 Tahun 2020 tentang Cipta Kerja dan peraturan pelaksanaannya PP Nomor 8 Tahun 2021 yang melahirkan PT Usaha Mikro kecil sebagai etintas baru dalam dunia usaha di Indonesia, telah menunjukkan keseriusan Pemerintah Indonesia mendukung UMK-M. Disamping itu dapat dilihat juga dalam usaha Pemerintah menembus peringkat 40 (empat puluh) besar yang sebelumnya diperingkat 73 program Ease of Doing Business (EoDB). EoDB merupakan survei yang diselenggarakan oleh World Bank, dimana EoDB terdiri atas 10 (sepuluh) indikator untuk meningkatkan iklim berbisnis di 189 negara di dunia. ${ }^{14}$ EoDB hanya memberikan penilaiannya terhadap bentuk usaha PT (Standardized Company). Artinya secara tidak langsung, kebijakan EoDB yang bermanfaat untuk UMK-M di Indonesia, hanya akan mendapat pengakuan positif dari World Bank apabila UMK-M tersebut berbentuk Perseroan Terbatas ${ }^{15}$.

Dalam hal ini yang dikatagorikan Usaha Mikro Kecil sebagaimana ditur dalam PP Nomor 7 Tahun 2021 antara lain: 1) Usaha Mikro adalah (a) usaha produktif milik orang perorangan dn/badan usaha perorangan; (b) memiliki modal usaha maksimal sampai dengan Rp 1 Miliar tidak termasuk tanah dan bangunan tempat usaha atau hasil penjualan tahunan sampai dengan maksimal Rp 2 miliar. 2) Usaha Kecil yaitu: (a) Usaha ekonomi produktif yang berdiri sendiri yang didirikan oleh orang perorangan atau badan usaha yang bukan merupakan anak usaha perusahaan atau bukan cabang perusahaan yang dimiliki, dikusai atau menjadi bagian langsung atau tidak langgsung dari usaha menengah atau besar; (b) memiliki modal usaha lebih dari Rp1 Miliar atau sampai dengan Rp 5 Miliar tidak termasuk tanah dan bangunan tempat usaha atau hasil penjualan tahunan sampai dengan Rp 2 Miliar sampai dengan Rp 15 Miliar.

Pendirian PT Usaha Mikro Kecil dapat didirikan 1 (satu) orang, dijelaskan dalam pasal 2 PP Nomor 8 Tahun 2021 ayat 1 b). Perseroan perorangan yang didirikan oleh 1 (satu) orang. Dengan berlakunya UndangUndang Cipta Kerja dan PP Nomor 8 Tahun 2021, maka ketentuan

${ }^{13}$ Ibid, h 71

${ }^{14}$ TheWorldBank,"AboutDoingBusiness"http://www.doingbusiness.org/content/da m/doingBusiness/media/Annual Reports/English/DB18 Chapters/DB18-About-Doing-

Business.pdf (diakses pada 17 April 2021)

${ }^{15}$ Ibid. 
mengenai syarat PT yang harus didirikan oleh 2 (dua) orang atau lebih tidak berlaku bagi Perseroan yang memenuhi kriteria untuk BUMN dan khususnya Usaha Mikro dan Kecil. Artinya, bagi BUMN, PT yang bergerak dipasar modal dan PT dengan kriteria Usaha Mikro dan Kecil dapat didirikan oleh satu orang.

Berbeda pada syarat pendirian PT yang diatur dalam UndangUndang PT yang harus didirikan oleh 2 orang atau lebih berdasarkan perjanjian, tujuannya agar bisa dikendalikan dan dikontrol oleh dua orang atau lebih, dan yang terpenting untuk untuk menjalankan fungsi "check and balances" dalam pengambilan keputusan strategis PT. Apabila syarat dua orang tidak dipenuhi akan berakibat pada tanggung jawab PT yang terbatas menjadi tanggung jawab tidak terbatas. Tanggung jawab tidak terbatas artinya segala perbuatan hukum dan kerugian PT menjadi tanggung jawab pendiri atau pemegang saham secara pribadi. Kondisi tersebut tentu saja bertentangan dengan prinsip Terbatas" yang selama ini berlaku ${ }^{16}$.

Dengan pendirian dibolehkan oleh satu orang dari ketentuan tersebut maka dalam pemilikan saham hanya orang perseroangan, sebagaimana disebutkan dalam Pasal 111 Undang-Undang Cipta Kerja yang menambahkan subtansi Pasal 153F Undang-Undang PT yang isinya bahwa : (1) Pemegang Saham Perseroan untuk Usaha Mikro dan Kecil dimaksud dalam Pasal 153A merupakan orang perseorangan; dan (2) Pendiri Perseroan hanya dapat mendirikan Perseroan Terbatas untuk Usaha Mikro dan Kecil sejumlah 1 (satu) Perseroan untuk usaha mikro dan kecil dalam 1 (satu) tahun. Ketentuan yang demikian ini menyimpangi kewajiban PT didirikan oleh minimal dua orang dengan melalui perjanjian. Sehingga dengan diaturnya pasal 153F UU Cipta Kerja dan pasal 2 PP Nomor 8 Tahun 2021, setiap orang dapat mendirikan PT seorang diri tanpa harus mencari partner asalkan bisnis yang dijalankan sesuai dengan kriteria Usaha Mikro dan Kecil. Hal ini akan berakibat bahwa PT didirikan dan dikendalikan oleh satu orang pemegang saham saja maka akan terbuka lebar kemungkinan adanya fraud yang dilakukan oleh pemegang saham yang bersangkutan terhadap pihak ketiga degan memanfaatkan terbatasnya tanggung jawab. ${ }^{17}$

${ }^{16}$ Munawar Kholil, Catatan Kritis Perubahan Lnscape Hukum Perseroan terbatas dalamUndang-undang Hak Cipta Kerja, RechtsVinding Online, h.3, https://rechtsvinding.bphn.go.id/view/view_online.php?id=348 diakses tanggal 3 April 2021

17 Mohammad Fais Aziz dan Nunuk Febrianingsih, Perseroan Terbatas (PT) Perseoranan Bagi Usaha Mikro Kecil (UMK) Melalui Rancangan Undang-Undang Cipta Keria, Jurnal Rechtvinding, Vol 9 Nomor 1 April 2020, h.12 
PT Usaha Mikro dan Kecil dalam proses pendiriannya dapat dilakukan tanpa melalui perjanjian dan akta notaris. Hal itu diatur dalam Pasal 111 angka 5 Undang-Undang Cipta Kerja yang didalamnya menambahkan subtansi Pasal 153A dan dipertegas lagi dalam pasal 6 PP Nomor 8 tahun 2021.

Pasal 153 A Undang-Undang Cipta Kerja menyebutkan bahwa:

(1) Perseroan yang memenuhi kriteria usaha mikro dan kecil dapat didirikan oleh 1 (satu) orang;

(2) Pendirian Perseroan untuk usaha mikro dan kecil sebagaimana dimaksud pada ayat (1) dilakukan berdasarkan surat pernyataan pendirian yang dibuat dalam Bahasa Indonesia;

(3) Ketentuan lebih lanjut mengenai pendirian Perseroan untuk usaha mikro dan kecil diatur dengan Peraturan Pemerintah.

Pasal 6 PP Nomor 8 Tahun 2021

(1) Perseroan perorangan didirikan oleh Warga Negara Indonesia dengan mengisi Pernyataan Pendirian dalam bahasa Indonesia.

(2) Warga Negara Indonesia sebagaimana dimaksud pada ayat (1) harus memenuhi persyaratan: a). berusia paling rendah 17 (tujuh belas) tahun; dan b). cakap hukum.

(3) Perseroan perorangan memperoleh status badan hukum setelah didaftarkan kepada Menteri dan mendapatkan sertifikat pendaftaran secara elektronik.

(4) Perseroan perorangan yang telah memperoleh status badan hukum sebagaimana dimaksud pada ayat (3) diumumkan oleh Menteri dalam laman resmi Direktorat Jenderal yang menyelenggarakan tugas dan fungsi di bidang administrasi hukum umum.

Ketentuan pasal 153A UU Cipta Kerja dan pasal 6 PP Nomor 8 Tahun 2021 menjelaskan bahwa pendirian Perseroan Usaha Mikro dan Kecil tanpa melibatkan peran Notaris dan hanya membuat surat Pernyataan Pendirian. Pasal 1 huruf (2) PP Nomor 8 Tahun 2021 Pernyataan Pendirian adalah format isian pendirian Perseroan perorangan yang didirikan oleh 1 (satu) crang secara elektronik. Tentunya Surat Pernyataan Pendirian tersebut bukanlah dikatagorikan sebagai suatu akta yang haru dibuat oleh pejabat publik atau dibuat oleh para pihak yang berkepentingan.

Pada dasarnya tumbuh kembangnya Perseroan Terbatas sebagai badan hukum yang memiliki konsekuensi pemegang hak dan kewajiban serta pemisahan harta kekayaan pribadi dengan harta Perusahaan terutama pada proses pendiriannya, dibutuhkan adanya Notaris terutama oleh 
masyarakat global sekarang ini yang bergerak dibidang bisnis. Selain memenuhi ketentuan kepastian hukum Undang-Undang PT yang mensyaratkan adanya akta pendirian dibuat oleh Notaris, Notaris diharapkan dapat memberikan perlindungan hukum bagi masyarakat dalam menjalankan usahanya.

Notaris sebagai Pejabat Umum diberikan perlindungan hukum oleh undang-undang dalam rangka memberikan kesaksian di pengadilan, karena akta otentik yang merupakan sebuah produk hukum yang dilahirkan oleh Notaris adalah pendukung terciptanya konsep kepastian hukum yang dibutuhkan oleh para pihak termasuk salah satunya adalah Akta Pendirian Perseroan Terbatas ${ }^{18}$. Demikian juga segala dokumen yang terkait PT seperti Anggaran Dasar, Risalah Rapat Umum Pemegang Saham (RUPS) dibuat dan dilegalisasi oleh Notaris.

Pendirian PT hanya melalui surat pernyataan tidak menjamin legalitas dokumen dan identitas pendiri. Legalitas PT akan diragukan dan beresiko karena bisa melakukan perbuatan melawan hukum, dan konsekuensinya PT sebagai badan hukum maka legalitas dokumen dan identitas pendiri harus dapat dipertanggungjawabkan. Sehingga dalam menjamin kepastian hukum dan perlindungan hukum, akta pendirian PT yang dibuat oleh notaris tetap diperlukan untuk menjamin legalitas PT, keabsahan dokumen dan identitas pendiri walaupun hanya PT untuk Usaha Mikro dan Kecil. ${ }^{19}$

Legalitas suatu perusahaan atau badan usaha adalah merupakan unsur yang terpenting, karena legalitas merupakan identitas diri yang melegalkan atau mengesahkan suatu badan usaha. Peran notaris sangat diperlukan untuk memastikan dokumen-dokumen yang dikirimkan secara elektronik ke pemerintah apabila memang dikirimkan oleh pihak yang sah, guna menghindari terjadinya penyalahgunaan wewenang. Dalam hal pendirian PT Usaha Mikro dan Kecil tersebut tidak ada dokumen fisik yang harus diberikan kepada pemerintah, hanya berbentuk scan dari dokumennya saja, dan pihak yang menandatangani pernyataan tersebut tidak bisa dipastikan dokumen telah ditandatangani langsung oleh pihak yang bersangkutan bersangkutan. Dengan demikian tidak diperlukannya akta notaris dalam pendirian perseroan Usaha Mikro dan Kecil akan mengakibatkan belum menjamin adanya kepastian hukum.

Kewenangan Notaris sebagai pejabat umum yang diatur dalam UndangUndang Nomor 30 Tahun 2004 dan telah dirubah dengan Undang-undang

18 Aman, Perlindungan Hukum Notaris Dalam Melaksanakan Rahasia Jabatan, Recital Review, Vol 2 No 1 (2019): Volume 1, Nomor 2, Juli2019

19 Ibid h.5, 
Nomor 2 Tahun 2014 dalam pembuatan akta otentik sesungguhnya menjadi bagian penting dari negara Indonesia yang menganut prinsip negara hukum dengan menjamin kepastian hukum, ketertiban dan perlindungan hukum. Ide dasar negara hukum baik dalam konsep "rechtsstaat" maupun "the rule of law" sasaran utamanya adalah perlindungan hak-hak dasar manusia. Dalam konsep rechtsstaat perlindungan hak-hak dasar diwujudkan melalui asas legalitas. Dengan asas tersebut, hukum harus dipositifkan, artinya hukum harus dibentuk secara sadar dan dituangkan dalam bentuk yang resmi dan pasti seperti dibuatnya Undang-Undang Nomor 02 Tahun 2014 tentang Perubahan Atas UU No. 30 Tahun 2004 tentang Jabatan Notaris ${ }^{20}$.

Untuk menentukan dengan jelas hak dan kewajiban seseorang sebagai subyek hukum dan terjaminnya kepastian hukum dalam berbagai hubungan di bidang ekonomi dan sosial termasuk perbankan, pertanahan maupun hubungan bisnis lainnya kebutuhan akan bukti tertulis berupa akta otentik sangat diperlukan dan terus meningkat sejalan dengan berkembangnya tuntutan baik pada tingkat nasional, regional dan global disamping dengan akta notaris akan menghindari terjadi sengketa diantara para pihak yang berkepentingan. sehingga diakui oleh masyarakat. Dengan kata lain, legalitas perusahaan harus sah menurut undang-undang dan peraturan, di mana perusahaan tersebut dilindungi atau dipayungi dengan berbagai dokumen hingga sah di mata hukum pada pemerintahan yan berkuasa saat itu. Keberlangsungan suatu usaha dipengaruhi oleh berbagai faktor, salah satunya adalah keberadaan unsur legalitas dari usaha tersebut. Dalam suatu usaha, legalitas suatu perusahaan atau badan usaha adalah merupakan unsur yang terpenting, karena legalitas merupakan identitas diri yang melegalkan atau mengesahkan suatu badan usaha sehingga diakui oleh masyarakat. Legalitas perusahaan harus sah menurut undang-undang dan peraturan, di mana perusahaan tersebut dilindungi atau dipayungi dengan berbagai dokumen hingga sah di mata hukum, lingkungan, dan banyak izinizin lainnya sesuai bidang usahanya masing-masing.

\section{KESIMPULAN}

PT Usaha Mikro dan Kecil berdasarkn PP nomor 8 tahun 2021 dalam proses pendiriannya dapat dilakukan tanpa melalui perjanjian dan akta notaris, hanya dengan membuat surat pernyataan. Pendirian PT hanya melalui surat pernyataan tidak menjamin legalitas dokumen dan identitas pendiri. Legalitas PT akan diragukan dan beresiko karena bisa melakukan

20 Bahder Johan Nasution, Penerapan Sanksi Administrasi Sebagai Sarana Pengendali Pembatasan Terhadap Kebebasan Bertindak Sebagai Notaris, Recital Review, Magister Kenotariatan Universitas Jambi Vol 2 No 1 (2020): Volume 2, Nomor 1, Januari 2020 
perbuatan melawan hukum, dan konsekuensinya PT sebagai badan hukum maka legalitas dokumen dan identitas pendiri harus dapat dipertanggungjawabkan. Oleh karena itu, akta pendirian PT yang dibuat oleh notaris tetap diperlukan untuk menjamin legalitas PT, keabsahan dokumen dan identitas pendiri walaupun hanya PT untuk Usaha Mikro dan Kecil.

Legalitas suatu perusahaan atau badan usaha adalah merupakan unsur yang terpenting, karena legalitas merupakan identitas diri yang melegalkan atau mengesahkan suatu badan usaha. Peran notaris sangat diperlukan untuk memastikan dokumen-dokumen yang dikirimkan secara elektronik ke pemerintah apabila memang dikirimkan oleh pihak yang sah, guna menghindari terjadinya penyalahgunaan wewenang. Dalam hal pendirian PT Usaha Mikro dan Kecil tersebut tidak ada dokumen fisik yang harus diberikan kepada pemerintah, hanya berbentuk scan dari dokumennya saja, dan pihak yang menandatangani pernyataan tersebut tidak bisa dipastikan dokumen telah ditandatangani langsung oleh pihak yang bersangkutan bersangkutan. Dengan demikian tidak diperlukannya akta notaris dalam pendirian perseroan Usaha Mikro Kecil akan mengakibatkan belum menjamin adanya kepastian hukum.

\section{DAFTAR PUSTAKA}

\section{Buku}

Fuady, Munir, 2003, Perseroan Terbatas Paradigma Baru, PT. Citra Aditya Bakti Bandung.

Harahap, M. Yahya, 2016, Hukum Perseroan Terbatas, cet.6, Sinar Grafika, Jakarta.

Kie, T.T. 2015, Studi Notariat: Beberapa Mata Pelajaran dan Serba-Serbi Praktek Notaris, Cetakan 3, Ichtiar Baru Van Hoeve, Jakarta.

ND. Fajar, Mukti dan Achmad, Yulianto, 2010, Dualisme Penelitian Hukum Normatif dan Hukum Empiris, Yogyakarta: Pustaka Pelajar,

Rudhi Prasetya, 2004, Kedudukan Mandiri Perseroan Terbatas, Citra Aditya Bakti, Bandung.

Sjaifurahman dan Adjie, Habib. 2011, Aspek Pertanggungjawaban Notaris dalam Pembuatan Akta, Bandung. CV. Mandar Maju.

Subekti, R., 1978, Hukum Pembuktian, Pradnya Paramita, Jakarta.

Widijaya, I.G. Rai, 2015 Hukum Perusahaan Megapoint Divisi dari Kesaint Blanc, Bekasi Indonesia.

Widjaja, Gunawan, 2008, 150 Tanya Jawab Tentang Perseroan Terbatas, Forum Sahabat, Jakarta. 


\section{Jurnal}

Aman, Perlindungan Hukum Notaris Dalam Melaksanakan Rahasia Jabatan, Recital Review, Vol 2 No 1 (2019): Volume 1, Nomor 2, Juli 2019

Aziz, Mohammad Fais Aziz dan Febrianingsih, Nunuk, Perseroan Terbatas (PT) Perseoranan Bagi Usaha Mikro Kecil (UMK) Melalui Rancangan Undang-Undang Cipta Kerja, Jurnal Rechtvinding, Vol 9 Nomor 1 April 2020.

Kholil, Munawar, Catatan Kritis Perubahan Lnscape Hukum Perseroan terbatas dalamUndang-undang Hak Cipta Kerja, RechtsVinding Online

https://rechtsvinding.bphn.go.id/view/view_online.php?id=348 (diakses tanggal 3 April 202)1

Nasution, Bahder Johan, Penerapan Sanksi Administrasi Sebagai Sarana Pengendali Pembatasan Terhadap Kebebasan Bertindak Sebagai Notaris, Recital Review, Magister Kenotariatan Universitas Jambi Vol 2 No 1 (2020): Volume 2, Nomor 1, Januari 2020

\section{Internet}

Arjana Bagaskara Solichin, PerseroanTerbatas Perseorangan Dari Kacamata Hukum Perseroan: Suatu Terobosan Baru dalam Kemudahan Berbisnis di Indonesia, https7://www.linkedin.com/pulse/perseroan-terbatas-perseorangandari-kacamata-hukum-arjana/?trk=public_profile_article_view (diakses tgl 13 april 2021)

TheWorldBank,

"About

Doing

Business" http://www.doingbusiness.org/content/dam/doingBusiness/media/An nualReports/English/DB18 Chapters/DB18-About-DoingBusiness.pdf (diakses pada 17 April 2021)

https://www.hukumonline.com/berita/baca/lt6035cf5909bc5/melihatkembali-kemudahan-berusaha-umkm-di-uu-cipta-kerja/) (diakses tanggal 9 April 2021)

https://grfandcolawfirm.com/omnibus-law-ruu-cipta-kerja-kini-pendirianbadan-hukum-dapat-dilakukan-oleh-1-orang/ (diakses 12 april 2021) 